\title{
PORĘCZENIE FUNDUSZU REGIONALNEGO JAKO PRAWNE ZABEZPIECZENIE DO USTANOWIONEGO LIMITU SKARBOWEGO NA RYNKU POZAGIEŁDOWYM
}

\section{Piotr Wybieralski ${ }^{*}$}

\section{REGIONAL FUND GUARANTEE AS A LEGAL COLLATERAL FOR TREASURY LIMIT IN THE OTC MARKET}

\begin{abstract}
The study highlights a selected aspect related to the financial risk management with the use of OTC derivatives, namely the issue of pre-settlement limits set by commercial banks for their counterparties, namely non-financial enterprises. The discussed situation assumes that the creditworthiness is sufficient in the opinion of the financial institution but the value of the legal collaterals proposed by the counterparty is insufficient. In this case, the use of guarantees of business support institutions such as regional funds may be particularly helpful. The formal and legal grounds for applying treasury limits were indicated and the way of their use was discussed, as well as a case study on the implementation of the mentioned guarantee for selected commercial bank. The article emphasizes the crucial role of scientific institutes in creating solutions to deal with real economic challenges.
\end{abstract}

Keywords: financial risk management, treasury limits, over-the-counter market, derivatives, guarantees.

JEL Class: F31, F37, G15.

\footnotetext{
* Doktor, Instytut Gospodarki Międzynarodowej, Uniwersytet Ekonomiczny w Poznaniu; https://orcid.org/0000-0001-82808465.
} 


\section{WSTĘP}

Innowacyjność w branży finansowej mająca na celu wykreowanie i budowę przewag rynkowych, zarówno na płaszczyźnie międzynarodowej, jak też lokalnej, związana jest obecnie nierzadko z koniecznością realizowania rozmaitych inicjatyw biznesowych w kooperacji z różnymi podmiotami. Przedmiotowa współpraca ma zazwyczaj charakter wielopłaszczyznowy i służy zarówno usprawnianiu dotychczas realizowanych procesów, jak również poszerzeniu i wzbogaceniu oferty produktowej (Trzepizur, 2016: 175-185; Korenik, 2017: 8-11; OECD, 2005: 48-55).

Celem opracowania jest przedstawienie mechanizmu funkcjonowania poręczenia cywilnego regionalnego funduszu poręczeń jako pośredniego zabezpieczenia dla limitu skarbowego wymaganego do zawieranych przez przedsiębiorstwa instrumentów pochodnych na rynku pozagiełdowym. Przedmiotowy schemat jest efektem zrealizowanej współpracy naukowo-biznesowej skutkującej zaproponowaniem oraz wdrożeniem innowacji w wybranym banku komercyjnym na terenie województwa Wielkopolskiego, polegającej na rozszerzeniu dotychczasowej oferty w zakresie produktów skarbowych, przede wszystkim instrumentów pochodnych. Dotychczas poręczenia funduszu były wykorzystywane w tym banku jako zabezpieczenie prawne do udzielonych kredytów obrotowych i inwestycyjnych, nie można było poręczać w ten sposób limitów skarbowych. W opracowaniu przedstawiono studium przypadku prezentujące okoliczności wyjściowe zaistniałego wyzwania gospodarczego oraz schemat wdrożonego rozwiązania.

Zgodnie z legislacją krajową i zagraniczną (Wybieralski, 2016: 442-444) instytucje finansowe, przede wszystkim banki umożliwiające swoim kontrahentom zawieranie instrumentów pochodnych powinny ustanowić tzw. transakcyjny limit skarbowy. Przedmiotowy limit zaliczany jest najczęściej do gamy instrumentów finansowania obrotowego, aczkolwiek na co należy zwrócić uwagę zazwyczaj nie występuje odrębna umowa samego limitu skarbowego, najczęściej jest to swoiste zawiadomienie wraz z informacją dodatkową dotyczącą jego wykorzystania. Brak formalnej umowy limitu skarbowego powoduje pewne komplikacje dla okołobiznesowych instytucji wspierających tj. fundusze poręczeń, które wyraźnie identyfikują ,produkty” finansowe, które mogą zostać objęte ich poręczeniem. Tym samym brakuje możliwości bezpośredniego poręczenia limitu skarbowego, właśnie ze względu na brak określonej jego definicji po stronie funduszu. Powoduje to, że podmioty uczestniczące $\mathrm{w}$ wymianie zagranicznej, pragnące mitygować ryzyko kursowe z wykorzystaniem pozagiełdowych instrumentów osłonowych, którym w ocenie banku brakuje zabezpieczeń, a mogłyby zastosować poręczenia funduszu, nie są w stanie skorzystać z oferty banku. Rozwiązaniem zaistniałego problemu było wykorzystanie instrumentów, które są powszechnie oznaczone po stronie funduszu, w tym przypadku kredytu odnawialnego na finansowanie 
działalności bieżącej. Przedmiotem takiego finansowania jest przede wszystkim wsparcie rozmaitych wydatków związanych z bieżącym funkcjonowaniem przedsiębiorstwa. Jest to zatem bardzo szerokie spektrum wydatków, które może być pod pewnymi warunkami odpowiednio zawężone np. do zrealizowanych różnic kursowych. Tym samym instytucja poręczeniowa, pomimo braku produktowej definicji limitu skarbowego była gotowa zabezpieczyć w ten sposób określony kredyt obrotowy. Mechanizm zakładał zatem sfinansowanie negatywnych różnic kursowych (w sytuacji nie wywiązania się kontrahenta banku z zawartych transakcji skarbowych) z oczekującego, będącego w gotowości finansowania obrotowego, poręczonego przez fundusz. Po stronie banku wyzwaniem było połączenie warunkowego kredytu obrotowego oraz limitu skarbowego w całość. Zaproponowano konstrukcję prawną z wykorzystaniem umowy limitu wierzytelności, w którym to zawiera się limit skarbowy na transakcje terminowe oraz warunkowy kredyt odnawialny z przeznaczeniem na różnice kursowe. W ten sposób powstał swoisty pakiet umożliwiający pośrednie zaimplementowanie poręczenia funduszu do limitu skarbowego w banku.

\section{WYBRANE RYZYKA TOWARZYSZĄCE ZAWIERANIU INSTRUMENTÓW POCHODNYCH}

Limity skarbowe są wykorzystywane w instytucji finansowej w celu zarządzania wybranym ryzykiem związanym $\mathrm{z}$ zawieraniem instrumentów pochodnych. Mowa o tzw. ryzyku przedrozliczeniowym, rozumianym jako możliwej do wystąpienia wskutek fluktuacji indeksów rynkowych stracie na zawartym kontrakcie, w trakcie jego funkcjonowania (Wybieralski, 2013: 89-91). Ryzyko to dotyczy całego okresu transakcji, od momentu zawarcia do daty jej rozliczenia. Poza ryzykiem przedrozliczeniowym występuje również ryzyko rozliczeniowe, związane $\mathrm{z}$ podstawieniem i wymianą pomiędzy stronami ustalonych w potwierdzeniu danego instrumentu kwot. Ten rodzaj ryzyka mitygowany jest najczęściej poprzez zachowanie kolejności realizowania płatności, oznaczającej konieczność zapewnienia na rachunku przez kontrahenta środków wynikających z zawartej transakcji, a w dalszej kolejności rozliczenia płatności przez bank (stosuje się zasadę delivery versus payment $)^{1}$. Na rynku pozagiełdowym $w$ relacji przedsiębiorstwo niefinansowe oraz instytucja finansowa wyzwaniem szczególnym jest przede wszystkim ryzyko przedrozliczeniowe. Pojawia się tutaj problematyka szacowania ryzyka rynkowego, a w dalszej kolejności wyceny samego instrumentu. Zmiana indeksów może wpływać pozytywnie lub negatywnie na wartość zawartego instrumentu pochodnego. Kontrakt może zyskiwać w pozytywnym scenariuszu, jak również tracić $\mathrm{w}$ negatywnym. W kontekście ryzyka przedroczlieniowego

${ }^{1}$ Bank może również zaproponować przygotowanie i udostępnienie tzw. limitu rozliczeniowego. 
uwzględniany jest przede wszystkim pesymistyczny scenariusz rozwoju sytuacji rynkowej. W celu oszacowania wielkości tego ryzyka wykorzystywana jest m.in. metoda wartości ryzykowanej (tj. VaR)2 . W metodzie tej oblicza się tzw. wagi ryzyka określające zakres zmienności na rynku bazowym w zadanym okresie funkcjonowania kontraktu przy danym poziomie ufności (najczęściej 95-99\%). Wagi te w poszczególnych instytucjach zazwyczaj się różnią, co wynika przede wszystkim z odmiennego sposobu szacowania zmienności. Niemniej jednak wagi te zazwyczaj wzrastają dla coraz to dłuższych terminów zapadalności kontraktów zakładając, że zmienność i tym samym ryzyko w horyzoncie dłuższym może być większe, aniżeli w okresie krótszym. Wartość ryzyka rynkowego kalibrowana jest jako iloczyn nominalnej kwoty kontraktu oraz procentowej wagi ryzyka dla danego okresu. Obliczona w ten sposób wielkość VaR wykorzystuje (umniejsza) przyznany limit skarbowy tym samym ograniczając możliwość zawierania kolejnych transakcji. Po zawarciu transakcji w ramach limitu skarbowego uwzględniana jest dodatkowo wartość bieżąca kontraktu. Wycena rynkowa wpływa na wielkość wykorzystania limitu skarbowego pozytywnie bądź negatywnie odpowiednio zwiększając bądź umniejszając dostępną kwotę limitu skarbowego. Zatem potencjalna strata oraz wycena rynkowa łącznie określają wielkość estymowanego ryzyka przedrozliczeniowego i są odzwierciedlone w wykorzystaniu limitu skarbowego. Należy zaznaczyć, iż w sytuacji, gdy negatywna wycena niezapadłych transakcji przekroczy kwotę ustalonego limitu skarbowego, instytucja finansowa jest uprawniona do przedterminowego zamknięcia transakcji i rozliczenia pozycji kontrahenta.

\section{PODSTAWY PRAWNE REGULUJĄCE FUNKCJONOWANIE LIMITÓW SKARBOWYCH}

Konieczność zastosowania przez instytucje finansowe ograniczeń w postaci limitów mających na celu ograniczenie różnych czynników ryzyka oraz ustalenie zasad postępowania w przypadku ich przekroczenia są wskazane m.in. w Ustawie Prawo Bankowe (por. art. 9b). O podobnych mechanizmach wspomina się w aspekcie instrumentów finansowych w ustawach i rozporządzaniach dotyczących rynku kapitałowego ${ }^{3}$. Jednak kwestia wykorzystania limitów transakcyjnych stosowanych w relacji ze swoim kontrahentem oraz wytycznych dotyczących zasad współpracy w obszarze produktów skarbowych w obszernym zakresie poruszana jest w Rekomendacji A Komisji Nadzoru Finansowego. W przedmiotowym

${ }^{2}$ „Wartość ryzykowana to maksymalna kwota, jaką można stracić w wyniku inwestycji w portfel o określonym horyzoncie czasowym i przy założonym poziomie ufności” por. Best, 2000: 23.

${ }^{3}$ Ustawa z dnia 29 lipca 2005 r. o nadzorze nad rynkiem kapitałowym; Ustawa z dnia 29 lipca 2005 r. o obrocie instrumentami finansowymi; Rozporządzenie Ministra Finansów z dnia 24.09.2012 r. w sprawie trybu i warunków postępowania firm inwestycyjnych, banków, o których mowa w art. 70 ust. 2 ustawy o obrocie instrumentami finansowymi, oraz banków powierniczych. 
dokumencie wskazuje się na konieczność podpisania odpowiedniego kompletu dokumentacyjnego oraz przydzielania limitu transakcyjnego (Rekomendacja A: 17). Kwota limitu ustalana jest na podstawie wskazanego we wniosku o limit skarbowy zapotrzebowania w zakresie danych transakcji (rynki, kwoty, terminy). $\mathrm{Z}$ kolei dostępność produktów bazuje na wyniku przeprowadzonego testu ankietowego, zgodnie z wytycznymi dyrektywy MIFID II $^{4}$. W ramach dokumentacji skarbowych otrzymywanej z banku oprócz umowy ramowej oraz ogólnych warunków współpracy dołączane są regulaminy poszczególnych instrumentów, dokumenty zawierające kluczowe informacje, scenariusze transakcji itp. Z kolei po zawarciu transakcji bank powinien przekazywać w ustalonych okresach aktualną wycenę zawartych kontraktów oraz informację w zakresie wykorzystania limitu skarbowego. W praktyce dealer walutowy sprawdza aktualną wielkość limitu przed potwierdzeniem transakcji oraz weryfikuje, czy dana transakcja może zostać zawarta. Po zawarciu transakcji wykorzystanie limitu jest codziennie monitorowane w odpowiednich jednostkach w banku. Gdy negatywna wycena kontraktu przekroczy kwotę limitu wówczas następuje konieczność zwiększenia (uzupełnienia) zabezpieczenia wymaganego transakcji lub dochodzi do przedterminowego zamknięcia oraz rozliczenia pieniężnego na rachunku bieżącym. Maksymalna strata $\mathrm{z}$ tytułu zawartych instrumentów pochodnych zostaje ograniczona do wielkości ustalonego limitu skarbowego.

\section{PORĘCZENIE CYWILNE FUNDUSZU W RAMACH UMOWY LIMITU WIERZYTELNOŚCI}

Podobnie jak ma to miejsce w przypadku różnego rodzaju kredytów dla limitów skarbowych wymagane jest również ustanowienie odpowiedniego prawnego zabezpieczenia wierzytelności banku. Generalnie udzielenie finansowania kredytobiorcy musi opierać się w pierwszej kolejności na wiarygodności oraz ocenie zdolności kredytowej i ryzyka związanego z ewentualnym brakiem spłaty zadłużenia. Niemniej jednak prawne zabezpieczenie stanowi wtórne źródło spłaty wierzytelności banku w przypadku pojawienia się niekorzystnych okoliczności, nieprzewidzianych $\mathrm{w}$ analizie kredytowej, ma również na celu zwiększenie prawdopodobieństwa wywiązania się kredytobiorcy ze swoich zobowiązań.

4 MIFID II tworzą akty prawne: (i) Dyrektywa Parlamentu Europejskiego i Rady nr 2014/65/UE z dnia 15 maja 2014 r. w sprawie rynków instrumentów finansowych oraz zmieniająca dyrek-tywę 2002/92/WE i dyrektywę 2011/61/UE, (ii) Rozporządzenie Parlamentu Europejskiego i Rady (UE) nr 600/2014 z dnia 15 maja 2014 r. w sprawie rynków instrumentów finansowych oraz zmieniające rozporządzenie (UE) nr 648/2012, (iii) Rozporządzenie Delegowane Komisji Europejskiej nr 2017/565 z dnia 25 kwietnia 2016r. uzupełniające dyrektywę Parlamentu Europejskiego i Rady 2014/65/UE w odniesieniu do wymogów organizacyjnych i warunków prowadzenia działalności przez firmy inwestycyjne oraz pojęć zdefiniowanych na potrzeby tej dyrektywy oraz szeregu rozporządzeń wykonawczych. 
W przypadku limitów skarbowych stosuje się analogiczne do kredytów prawne formy zabezpieczenia wierzytelności, zaczynając od osobowych na rzeczowych kończąc (Chynał, 2011: 21-26; Koleśnik i Rewieński, 2008). W przypadku pierwszej grupy zabezpieczeń wtórnym źródłem spłaty jest cały majątek zabezpieczającego, zalicza się m.in. gwarancje, poręczenia cywilne, weksel, przelew wierzytelności. Zabezpieczenia te, mimo że dają bankowi prawo do dochodzenia roszczenia $z$ całego majątku osoby zabezpieczającej, nie uprawniają do żadnego konkretnego składnika tego majątku. Z kolei w przypadku zabezpieczeń rzeczowych wtórnym źródłem spłaty zaangażowania kredytowego są środki uzyskane $\mathrm{z}$ realizacji przedmiotu zabezpieczenia, zalicza się m.in. kaucję (przelew środków na rachunek banku), blokadę środków na rachunku bankowym, zastaw rejestrowy, zastaw zwykły, przewłaszczenie, hipotekę i inne.

Omawiany w niniejszym opracowaniu problem zastosowania poręczenia cywilnego funduszu jako zabezpieczenia dla limitu skarbowego ujawnia się w sytuacji, kiedy firma posiada zdolność kredytową, ale brakuje jej właśnie odpowiedniej wartości ustanowionych zabezpieczeń (szerzej nt. funduszy poręczeniowych Bartkowiak, 2009; Janc i Waliszewski, 2014; Wolański, 2017). Ze względu na brak zdefiniowanego produktu, jakim jest limit skarbowy regionalny fundusz nie był w stanie udzielić bezpośredniego poręczenia. Stąd wymagane było wprowadzenie innowacyjności polegającej na poręczeniu kredytu odnawialnego z przeznaczeniem na rozliczenie negatywnej wyceny instrumentów pochodnych. $\mathrm{Ze}$ względu na fakt występowania limitu skarbowego oraz kredytu obrotowego zastosowano konstrukcję prawną limitu wierzytelności. Po opracowaniu wstępnej koncepcji pośredniego poręczenia limitu skarbowego w ramach limitu wierzytelności oraz przeprowadzonych konsultacjach podjęto równoległe działania przygotowawcze zarówno w funduszu oraz banku (patrz tab. 1).

W maju 2016 skierowano do prezesa regionalnego funduszu poręczeń ${ }^{5}$ komunikację mailową przedstawiającą podstawy prawne zawieranych w banku kontraktów terminowych. Przekazano wzorzec umowy ramowej na transakcje kasowe i pochodne oraz wybrane regulaminy, jak również ogólne warunki współpracy w zakresie transakcji kasowych i pochodnych. Pojawiła się wstępna odpowiedź zwrotna ze strony funduszu akceptująca udzielenie poręczenia do kredytu odnawialnego w celu rozliczenia transakcji terminowych w ramach limitu skarbowego w konstrukcji limitu wierzytelności.

${ }^{5}$ Głównym zadaniem funduszu jest świadczenie pomocy mikro, małym i średnim przedsiębiorstwom z terenu województwa Wielkopolskiego w postaci udzielania poręczeń spłaty m.in. pożyczek, kredytów, leasingów. Podstawowe informacje na temat aktywności funduszy poręczeniowych działających na przestrzeni 2019 w Polsce można odnaleźć w Raporcie Krajowego Stowarzyszenia Funduszy Poręczeniowych (Gajewski i in., 2020). 
Tabela 1. Harmonogram realizowanych działań

\begin{tabular}{|c|c|}
\hline Etapy & Charakterystyka \\
\hline I & $\begin{array}{r}\text { Zidentyfikowane wyzwanie praktyczne - zasygnalizowanie przez kontrahenta } \\
\text { banku intencji dot. zawarcia instrumentu zabezpieczającego; po stronie banku } \\
\text { braku możliwości ustanowienia limitu skarbowego ze względu na } \\
\text { niewystarczającą wartość prawnych zabezpieczeń }\end{array}$ \\
\hline II & $\begin{array}{r}\text { Rozpoznanie możliwości udzielenia poręczenia regionalnego funduszu dla limitu } \\
\text { skarbowego - brak możliwości bezpośredniego wsparcia }\end{array}$ \\
\hline III & $\begin{array}{r}\text { Zaproponowanie konstrukcji poręczenia cywilnego funduszu dla kredytu } \\
\text { odnawialnego z przeznaczeniem na rozliczenie instrumentów pochodnych } \\
\text { w ramach limitu skarbowego w konstrukcji limitu wierzytelności - } \\
\text { wstępna akceptacja }\end{array}$ \\
\hline IV & $\begin{array}{c}\text { Maj-lipiec 2016 formalne kontakty mające na celu przygotowanie i opracowanie } \\
\text { stosownej dokumentacji, zakończonej wdrożeniem poręczenia w lipcu } 2016 \mathrm{r} .\end{array}$ \\
\hline
\end{tabular}

Źródło: opracowanie własne.

Na początku czerwca 2016 roku został przygotowany aneks do umowy generalnej z funduszem, rozszerzający zakres przedmiotowy poręczeń. W połowie czerwca tego roku przygotowane zostały w banku zaktualizowane procedury oraz draft decyzji wprowadzającej przedmiotowe zmiany, zostały doprecyzowane warunki raportowania przez bank do funduszu danych o kredytach poręczonych (terminy oraz zakres raportu). Po uzyskaniu pozytywnych opinii ze wszystkich jednostek uczestniczących $\mathrm{w}$ procesie wdrożenia nowego produktu w banku została podjęta na początku lipca 2016 decyzja o wprowadzeniu zmian w procedurach funduszy poręczeniowych - wprowadzenie limitu wierzytelności dla funduszu Wielkopolskiego. W tym samym terminie został podpisany aneks do umowy generalnej pomiędzy funduszem a bankiem, reprezentowanym odpowiednio przez prezesa zarządu funduszu oraz dyrektora regionu banku w Poznaniu.

Umowa limitu wierzytelności zakłada możliwość skorzystania z kilku produktów w ramach jednego wspólnego zabezpieczenia. Tym samym pojawia się jedna decyzja kredytowa, jedna umowa oraz jedno wspólne zabezpieczenie dla wszystkich współistniejących kredytów/produktów (tj. kredyt w rachunku bieżącym, kredyt w rachunku kredytowym, gwarancje lub poręczenie bankowe, limit na produkty skarbowe i in.). Limit taki ma zazwyczaj charakter odnawialny, co oznacza, że każda spłata całości lub części zadłużenia z tytułu produktów udzielonych w ramach limitu wierzytelności powoduje, iż limit odnawia się w tym zakresie i może być ponownie wykorzystany w terminie do dnia ostatecznego rozliczenia. 
W omawianym $\mathrm{w}$ niniejszym opracowaniu przypadku połączenia kredytu oraz limitu skarbowego w umowie limitu wierzytelności, pojawia się kredyt odnawialny najczęściej w rachunku kredytowym, z przeznaczeniem wyłącznie na płatności z nierozliczonych transakcji terminowych. Wykorzystanie takiego kredytu następuje na podstawie dyspozycji banku, stąd kredytobiorca powinien podpisać pełnomocnictwo dla banku do obciążania kredytu w przypadku braku środków na rozliczenie transakcji skarbowych na rachunkach bieżących. Natomiast ustanowionym zabezpieczeniem dla limitu wierzytelności jest poręczenie cywilne funduszu w odpowiedniej wysokości. Należy zwrócić uwagę, iż w specyfikacji warunków poszczególnych składowych limitu wierzytelności wskazana jest kwota sublimitu z przeznaczeniem na kredyt odnawialny w rachunku kredytowym, z podkreśleniem przeznaczenia na rozliczenie transakcji zawieranych $\mathrm{w}$ ramach limitu skarbowego, dzień ostatecznej spłaty, jak również koszty (określona marża banku wraz z odpowiednim indeksem $\mathrm{z}$ rynku pieniężnego ${ }^{6}$ ). W ramach zakresu produktowego $\mathrm{w}$ limicie wierzytelności oprócz kredytu z przeznaczeniem na różnice kursowe wskazany jest także w tej samej kwocie limit na transakcje skarbowe. Termin jego zapadalności jest zazwyczaj nieco krótszy niż dzień ostatecznej spłaty kredytu oraz samego limitu wierzytelności. W umowie limitu wierzytelności w punkcie dotyczącym wykorzystania wskazany jest sposób określenia kwoty wierzytelności banku, która to wynika z zapisów umowy ramowej na transakcje kasowe i pochodne. W podobny sposób określona zostaje data wymagalności (poprzez nawiązanie do stosownych zapisów umowy ramowej na transakcje kasowe i pochodne). W dalszej kolejności zostaje podpisana umowa poręczeniowa pomiędzy funduszem a bankiem, na podstawie wniosku kredytobiorcy o udzielenie poręczenia spłaty zobowiązań z tytułu kredytu odnawialnego funkcjonującego w ramach limitu wierzytelności. Poręcznie takie najczęściej nie obejmuje całej kwoty (zazwyczaj ok $80 \%$ wartości limitu skarbowego), bez odsetek i innych kosztów związanych z udzielonym kredytem. Warunkiem udzielenia poręczenia jest przyjęcie przez bank od kredytobiorcy zazwyczaj zabezpieczenia spłaty poręczenia $\mathrm{w}$ formie weksla in blanco $\mathrm{z}$ deklaracją wekslową wystawionego na rzecz funduszu przez kredytobiorcę oraz opłacenie opłaty prowizyjnej za udzielenia poręczenia.

\section{UWAGI KOŃCOWE}

Pierwsze wykorzystanie nowo opracowanego produktu nastąpiło jeszcze w tym samym 2016 roku przez przedsiębiorstwo z terenu Wielkopolski o profilu działalności opisywanym przez PKD 01.61. Z (działalność usługowa wspomagająca produkcję roślinną). Podmiot ten został zweryfikowany zarówno przez regionalny

\footnotetext{
${ }^{6}$ Koszty te pojawią się w momencie wykorzystania produktu.
} 
fundusz oraz oddział banku. Zawarty instrument pochodny związany był z udzielonym finansowaniem i dotyczył zamiany waluty oraz kwoty z PLN na EUR, gdyż przedsiębiorstwo generuje część swoich przychodów właśnie w tej walucie. W kolejnych latach omawiana konstrukcja produktowa wykorzystywana była wielokrotnie w banku na terenie Wielkopolski.

Innowacyjność w branży finansowej, jak wspomniano we wstępie niniejszego opracowania ujawnia się na wielu płaszczyznach. Dotyczy aspektów technologicznych (tj. blockchain, Big Data itp.), realizowania rozmaitych procesów biznesowych oraz finalnych produktów i usług przeznaczonych zarówno dla klienta detalicznego jak również przedsiębiorstw. Problematyka omawianego poręczenia dla limitu skarbowego dotyka bardzo szczególnego obszaru, gdyż dotyczy współpracy banku z klientem biznesowym, która to ze względu na swoją specyfikę ma szczególne, indywidualne znaczenie. W tym segmencie standardem stają się rozwiązania ,szyte na miarę”, dopasowane do konkretnych potrzeb. Takim przykładem jest niewątpliwie kredyt obrotowy i limit skarbowy w ramach limitu wierzytelności z poręczeniem regionalnego funduszu.

Innowacje w branży finansowej powstają nierzadko w kooperacji z różnymi podmiotami, zarówno biznesowymi, jak też okołobiznesowymi, czy też instytutami naukowymi (rysunek 1$)^{7}$.

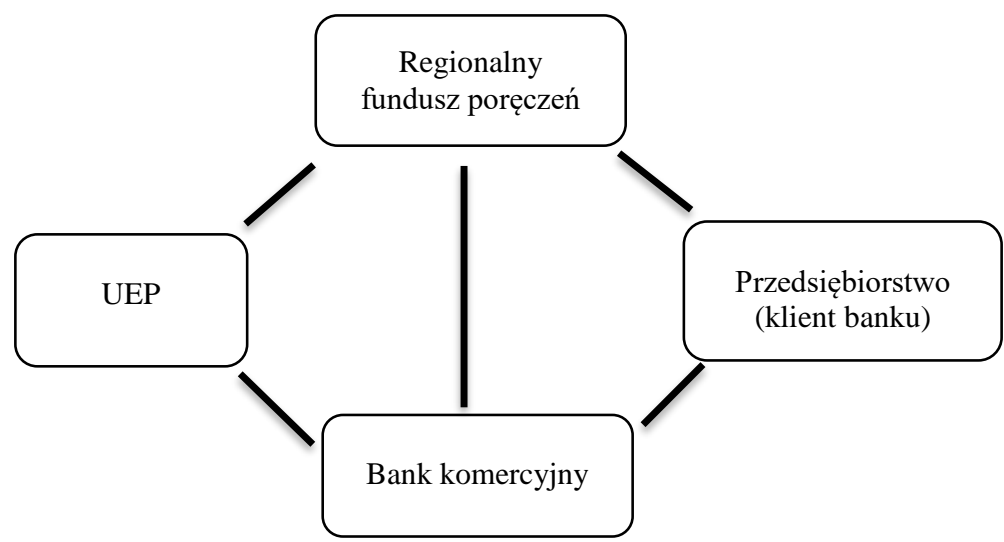

Rysunek 1. Schemat kooperacji naukowo-biznesowej w przypadku opisywanej innowacji produktowej

Źródło: opracowanie własne.

${ }^{7}$ Zaangażowanymi w projekt byli pracownicy Uniwersytetu Ekonomicznego w Poznaniu, jak również regionalnego funduszu poręczeń oraz jednego z banków komercyjnych notowanych na GPW na terenie województwa Wielkopolskiego. 
W tym przypadku obecność pracowników naukowych była zaakcentowana na wszytkach etapach rozwoju omawianego produktu. Zaczynając od rozwiązań koncepcyjnych po schematy wdrożeniowe. Przenikanie wiedzy pomiędzy praktyką a nauką jest obecnie niezmiernie istotne dla obu stron. Szczególnie dzisiaj, coraz częściej oczekuje się od naukowców zidentyfikowania wyzwań praktycznych oraz zaproponowania stosownych rozwiązań i pomocy w ich wdrożeniu. Biznes korzysta i buduje swoje przewagi rynkowe dzięki wprowadzonej innowacji, nauka zaś akcentuje swój aplikacyjny charakter, swój bezpośredni wpływ społeczny.

\section{BIBLIOGRAFIA}

Bartkowiak, B. (2009). Fundusze pożyczkowe i poręczeniowe $w$ finansowaniu matych i średnich przedsiębiorstw w Polsce. Warszawa: CeDeWu.

Best, P. (2000). Wartość narażona na ryzyko. Kraków: Dom Wydawniczy ABC.

Chynał, H. (2011). Kredyty bankowe i inne formy finansowania. Warszawa: Difin.

Dyrektywa 2014/65/UE Parlamentu Europejskiego i Rady z dnia 15 maja 2014 r. w sprawie rynków instrumentów finansowych oraz zmieniająca dyrektywę 2002/92/WE i dyrektywę 2011/61/UE, Dz.Urz. UE L 173 z dnia 12.06.2014 r.

Gajewski, M., Kubajek, R. i Szczucki J. (2020). Rynek lokalnych i regionalnych funduszy poręczeniowych $w$ Polsce $w 2019$ r., Krajowe Stowarzyszenie Funduszy Poręczeniowych KSFP, https://ksfp.org.pl/wp-content/uploads/2020/09/Raport__poreczenia_2019.pdf [dostęp 26.01.2021].

Janc, A. i Waliszewski, K. (2014). Fundusze poręczeniowe i pożyczkowe w finansowym wsparciu sektora mikro-, małych i średnich przedsiębiorstw. Warszawa: CeDeWu.

Koleśnik, J. i Rewieński, M. (2008). Zabezpieczania w bankowości - aspekty prawne i wymogi regulacyjne. Warszawa: Wolters Kluwer Polska sp. z o.o.

Korenik, D. (2017). Pozytywne i negatywne innowacje w nowoczesnej bankowości. Studia Ekonomiczne. Zeszyty Naukowe Uniwersytetu Ekonomicznego w Katowicach, 346, s. 7-20.

OECD, (2005). Oslo Manual. Guidelines for Collecting and Interpreting Innovation Data, $3^{\text {rd }}$ Edition, OECD and Statistical Office of the European Communities, doi.org/10.1787/9789264013100-en

Rekomendacja A (2010) dotycząca zarządzania ryzykiem towarzyszącym zawieraniu przez banki transakcji na rynku instrumentów pochodnych, KNF, Warszawa.

Rozporządzenie Delegowane Komisji Europejskiej nr 2017/565 z dnia 25 kwietnia 2016 r. uzupełniające dyrektywę Parlamentu Europejskiego i Rady 2014/65/UE w odniesieniu do wymogów organizacyjnych i warunków prowadzenia działalności przez firmy inwestycyjne oraz pojęć zdefiniowanych na potrzeby tej dyrektywy, Dz. Urz. UE L 87 z dnia 31.03.2017 r.

Rozporządzenie Ministra Finansów z dnia 24.09.2012 r. w sprawie trybu i warunków postępowania firm inwestycyjnych, banków, o których mowa w art. 70 ust. 2 ustawy o obrocie instrumentami finansowymi, oraz banków powierniczych, Dz.U. 2012, poz. 1078.

Rozporządzenie Parlamentu Europejskiego i Rady (UE) nr 600/2014 z dnia 15 maja 2014 r. w sprawie rynków instrumentów finansowych oraz zmieniającego rozporządzenie (UE) nr 648/2012, Dz. Urz. UE L 173 z dnia 12.06.2014 r.

Trzepizur, P. (2016). Zarządzanie innowacjami w sektorze usług bankowych. Zeszyty Naukowe Politechniki Częstochowskiej, Zarządzanie, 23(t. 2), s. 175-185, doi:10.17512/znpcz.2016.3.2.17 
Ustawa o Obrocie Instrumentami Finansowymi z dnia 29 lipca 2005 r., Dz.U. 2005, nr 183, poz. 1538. Ustawa Prawo Bankowe z dnia 29 sierpnia 1997 r., Dz.U. 1997, nr 140, poz. 939.

Wolański, R. (2017). Fundusze pożyczkowe i poręczeniowe a małe i średnie przedsiębiorstwa wzajemne interakcje. Wspótczesne Finanse. Teoria $i$ Praktyka, 1, s. 53-66, doi:10.18276/wf.2017.1-06

Wybieralski, P. (2013). Wykorzystanie metody Value at Risk (VaR) w procesie zarządzania ryzykiem kursowym z zastosowaniem derywatów walutowych na rynku pozagiełdowym (OTC). W: Wybrane problemy nauki ekonomii, finansów i bankowości. Kalisz: Wyd. PWSZ w Kaliszu, s. 87-98.

Wybieralski, P. (2016). Otoczenie legislacyjne regulujące funkcjonowanie transakcyjnych limitów skarbowych w relacji z przedsiębiorstwem niefinansowym na walutowym rynku pozagiełdowym. Finanse, Rynki Finansowe, Ubezpieczenia, 1(79), s. 441-448, doi:10.18276/frfu.2016.79-34.

\section{PORĘCZENIE FUNDUSZU REGIONALNEGO JAKO PRAWNE ZABEZPIECZENIE DO USTANOWIONEGO LIMITU SKARBOWEGO NA RYNKU POZAGIEŁDOWYM}

\section{Streszczenie}

W opracowaniu zwrócono uwagę na wybrany aspekt związany z problematyką zarządzania ryzykiem finansowym z wykorzystaniem instrumentów pochodnych na rynku pozagiełdowym, a mianowicie kwestią prawnego zabezpieczenia do ustanowionych przez banki komercyjne dla swoich kontrahentów - przedsiębiorstw niefinansowych limitów skarbowych. Omawiana jest sytuacja zakładająca wystarczającą w ocenie instytucji finansowej zdolność kredytową kontrahenta, ale niewystarczającą wartość proponowanych przez niego prawnych zabezpieczeń wierzytelności bankowych. W tym przypadku zastosowanie poręczeń cywilnych okołobiznesowych instytucji wspierających tj. regionalne fundusze może być szczególnie pomocne. Wskazano na formalno-prawne przesłanki stosowania limitów skarbowych oraz omówiono sposób ich wykorzystania, jak również przedstawiono studium przypadku dotyczące wdrożenia omawianego poręczenia dla wybranego oddziału banku komercyjnego. W artykule podkreślono szczególnie istotną rolę instytutów naukowych w kreowaniu rozwiązań dla rzeczywistych wyzwań gospodarczych.

Słowa kluczowe: zarządzanie ryzykiem finansowym, limity skarbowe, rynek pozagiełdowy, instrumenty pochodne, poręczenie cywilne. 